\title{
Karyotype of the gall fly Tomoplagia rudolphi (Lutz \& Lima) (Diptera, Tephritidae)
}

\author{
Marco Antônio A. Carneiro ${ }^{1,2}$ \\ Luiz Fernando Gomes ${ }^{3}$ \\ Silvia das Graças Pompolo ${ }^{3}$ \\ Lucio Antonio de Oliveira Campos ${ }^{3}$
}

\begin{abstract}
The objective of the present study is to describe the karyotype of the fruit fly Tomoplagia rudolphi (Lutz \& Lima, 1918). This fly induces the formation of galls on the stems of Vernonia polianthes (Asteraceae). The cytogenetic analysis of cerebral ganglia (larva and pupa) and testis (adults) of T. rudolphi showed a diploid chromosome number of $2 n=10+X X$ (female) and $2 n=10+X Y$ (male). The diploid chromosome number $2 n=12$ and the $\mathrm{XX} / \mathrm{XY}$ sex determination system have been found in most of the species studied. The present investigation constitutes the first cytogenetics study of the genus Tomoplagia Coquilltt, 1910.

KEY WORDS. Chromosome, Cyclorrhapha, cytogenetic, fruit fly, sex determination system
\end{abstract}

Species of the family Tephritidae have been extensively studied because of their economic importance, especially those belonging to the genera Rhagoletis Loew, 1862 and Anastrepha Schiner, 1868, which are important pests infesting apples and other fruits all over the world (BORROR et al. 1989). Other species belonging to various tephritid genera are gall inducers (MANI 1964; DREGER-JAUFFRET \& SHORTHOUSE 1992). Tomoplagia rudolphi (Lutz \& Lima, 1918) lay eggs in shoot apical meristems. Larvae feed on cells of the medullar parenchyma and gall tissue proliferates as the larvae develop, resulting in a globulous gall. Adults emerge 15 to 20 days after oviposition to begin a new reproductive cycle (ANDRADE et al. 1995; SiLva et al. 1996).

The family Tephritidae is poorly known in terms of its cytogenetics and few studies were conducted on pests species (CANOVAI et al. 1994; ZAMBETAKI et al. 1995). However, two patterns have emerged thus far and are becoming more clear. Within the family Tephritidae the diploid chromosome number of 12 is thought to be the rule and the male, the heterogametic sex (SOLFERINI \& MORGANTE 1987, see table I). In the present study we examined the karyotype of the gall inducer Tomoplagia rudolphi. This is the first time that a study was conducted on the karyotype of a species belonging to the genus Tomoplagia Coquillett, 1910.

1) Curso de Pós-graduação em Entomologia, Departamento de Biologia Animal, Universidade Federal de Viçosa. 36571-000 Viçosa, Minas Gerais, Brasil.

2) Departamento de Ciências Biológicas, ICEB, Universidade Federal de Ouro de Preto. 35400-000 Ouro Preto, Minas Gerais, Brasil.

3) Laboratório de Citogenética e Evolução, Departamento de Biologia Geral, Universidade Federal de Viçosa. 36571-000, Viçosa, Minas Gerais, Brasil. 


\section{MATERIAL AND METHODS}

Species of the genus Tomoplagia are endemic to the Neotropical Region, and about 44 species have been described so far. T. rudolphi induces the production of galls in stems of Vernonia polianthes (Asteraceae). Galls are monothalamous presenting a variable number of larvae (SILVA et al. 1996). Galls of Vernonia polianthes Less containing larva and pupa of T. rudolphi were collected in three different sites in Viçosa, Minas Gerais, Brazil. Two sites were located in campus of the Universidade Federal de Viçosa, and the third one along the highway, which runs from Viçosa to Coimbra. The galls were collected randomly in each region during January and February 1996. Galls containing larvae, young pupae and adults were collected and taken to the laboratory. Slides preparation were carryed out using cerebral ganglion cells of larva and pupa according to the technique of IMAI et al. (1988). In order to differentiate the male and female karyotypes germinative tissue from of adult males cells was also analysed. A total of 604 metaphases were obtained from 24 specimens (20 larva, 2 pupa and 2 adults) found in 14 galls from three different populations were analysed. Chromosomes were cut out and mounted in decreasing order of size and the morphology was classified according to the nomenclature by LEVAN et al. (1964).

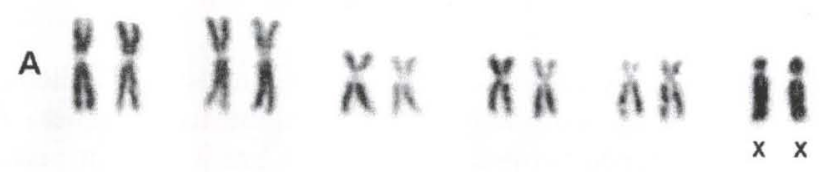

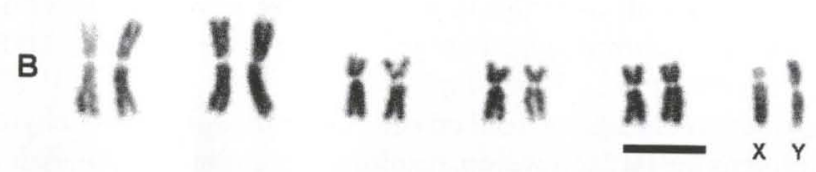

Fig. 1. Karyotype of Tomoplagia rudolphi, $2 n=12$ chromosomes. (A) female; (B) male. Bar $=5 \mu \mathrm{m}$.

\section{RESULTS AND DISCUSSION}

All individuals of Tomoplagia rudolphi presented the diploid chromosome number $2 n=12$ chromosomes. With the analysis of pupa and larva, two karyotypes were detected. The first consisted of 12 submetacentric chromosomes, and second consisted of 11 submetacentric chromosomes, and one metacentric chromosome (Fig. 1). Male germ cells presented the metacentric chromosome showing that the male is the heterogametic sex. On basis in this observations the sex determination system in T. rudolphi is XX in the female (Fig. 1A) and the XY in the male (Fig. 1B). The present study agrees with previous reports, which showed that in the family Tephritidae the diploid chromosome number is $2 n=12$ (Tab. I). Only two species did not present $2 \mathrm{n}=12$ chromosomes, $A$. pickeli Lima, $1934(2 \mathrm{n}=8)$ and $R$. meigenii (Loew, 1844) (male $2 \mathrm{n}=9$; female $2 \mathrm{n}=10$ ), and the males of $A$. bistrigata Bezzi, 
1919 and A. serpentina (Wiedemann, 1830) $(2 \mathrm{n}=11)$. The most frequent sex determination system is $\mathrm{XX} / \mathrm{XY}$ found in 13 out of 17 species. In only three species it was found a different sex determination system. A. bistrigata and A. serpentina, $\left(\mathrm{X}_{1} \mathrm{X}_{1} \mathrm{X}_{2} \mathrm{X}_{2} / \mathrm{X}_{1} \mathrm{X}_{2} \mathrm{Y}\right)$, R. meigenii $(\mathrm{XX} / \mathrm{X} 0)$ and no sex chromosome was detected in Rhagoletis berberidis Jermy, 1961 (Tab. I).

Table I. Diploid number and sex determination systems of Tephritidae species.

\begin{tabular}{|c|c|c|c|c|c|}
\hline \multirow[t]{2}{*}{ Species } & \multicolumn{2}{|c|}{$\begin{array}{l}\text { Chromosome } \\
\text { number }(2 n)\end{array}$} & \multicolumn{2}{|c|}{$\begin{array}{l}\text { Sex determination } \\
\text { system }\end{array}$} & \multirow[t]{2}{*}{ Authors } \\
\hline & Male & Female & Male & Female & \\
\hline Anastrepha barnesi Aldrich, 1925 & 12 & 12 & $x x$ & $\mathrm{xx}$ & SOLFERINI \& MORGANTE (1987) \\
\hline A. bistrigata Bezzi, 1919 & 12 & 11 & $\times 1 \times 1 \times 2 \times 2$ & $\times 1 \times 2 Y$ & SOLFERINI \& MORGANTE (1987) \\
\hline A. fraterculus (Wiedemann, 1830) & 12 & 12 & $x x$ & $X Y$ & SOLFERINI \& MORGANTE (1987) \\
\hline A. obliqua (Macquart, 1835) & 12 & 12 & $x x$ & $X Y$ & SOLFERINI \& MORGANTE (1987) \\
\hline A. pickeli Lima, 1934 & 08 & 08 & $x x$ & $X Y$ & SOLFERINI \& MORGANTE (1987) \\
\hline A. pseudoparallela (Loew, 1873) & 12 & 12 & $x x$ & $X Y$ & SOLFERINI \& MORGANTE (1987) \\
\hline A. serpentina (Wiedemann, 1830) & 12 & 11 & $x 1 \times 1 \times 2 \times 2$ & $\mathrm{X} 1 \mathrm{X} 2 \mathrm{Y}$ & SOLFERINI \& MORGANTE (1987) \\
\hline A. striata Schiner, 1868 & 12 & 12 & $x x$ & $X Y$ & SOLFERINI \& MORGANTE (1987) \\
\hline Bactrocera oleae (Gmelin, 1790) & 12 & 12 & $x x$ & $X Y$ & MAVRAGANI-TSIPIDOU et al. (1992) \\
\hline Ceratitis capitata (Wiedemann, 1824) & 12 & 12 & $x x$ & $X Y$ & ZACHAROPOULOU (1987) \\
\hline Rhagoletis berberidis Jermy, 1961 & 12 & 12 & * & & BUSH \& BOLLER (1977) \\
\hline R. cerasi (Linnaeus, 1758) & 12 & 12 & $x x$ & $X Y$ & BUSH \& BOLLER (1977) \\
\hline R. meigenii (Loew, 1844) & 10 & 09 & $x x$ & $x_{0}$ & BUSH \& BOLLER (1977) \\
\hline Tomoplagia rudolphi (Lutz \& Lima, 1918) & 12 & 12 & $x x$ & $X Y$ & Present Study \\
\hline Trupanea chrysanthemifolli Frias, 1985 & 12 & 12 & $x x$ & $X Y$ & FRIAS (1985) \\
\hline T. foliosi Frias, 1985 & 12 & 12 & $x x$ & $X Y$ & FRIAS (1985) \\
\hline T. thuriferae Frias, 1985 & 12 & 12 & $x x$ & $X Y$ & FRIAS (1985) \\
\hline
\end{tabular}

$\left(^{*}\right)$ Sex chromosomes not identified.

ACKNOWLEDGMENTS. We thank E.S.A. Marques e Dr. R.A. Zucchi for taxon identification, and two anonymous reviewers for their comments on early drafts of this manuscript. M.

A.A.C. received financial support from $\mathrm{CNPq}$ (\# 131245/95-3).

\section{REFERENCES}

ANDRADE, G.I.; I.M. Silva; G.W. Fernandes \& V.L. Scatena. 1995. Aspectos biológicos das galhas de Tomoplagia rudolphi (Diptera: Tephritidae) em Vernonia polyanthes (Asteraceae). Rev. Brasil. Biol. 55: 819-829.

BORROR, D.J.; C.A. TRIPLEHORN \& N.F. JONHSON. 1989. An introduction to the study of insects. Philadelphia, Saunders College, XIV+875p.

BUSH, G.L. \& E. BolLER. 1977. Chromosome morphology of the Rhagoletis cerasi species complex (Diptera, Tephritidae). Ann. Ent. Soc. Amer. 70: 316-318.

Canovai, R.; B. CATERINI; L. ConTAdini \& L. Galleni. 1994. Karyology of the medfly Ceratitis capitata (Wied.) mitotic complement: ASG bands. Caryologia 47: 241-247.

DREgER-JAufFret, F. \& J.D. Shorthouse. 1992. Diversity of gall-inducing insects and their galls, p.8-33. In: J.D. SHORTHOUSE \& O. ROHFRITSCH (Eds). Biology of insect-induced galls. New York, Oxford University, X+275p.

FRÍAS, D.L. 1985. Cuatro nuevas especies chilenas del genero Trupanea Shrank (Diptera, Tephritidae). Revta bras. Zool. 2: 363-381. 
IMAI, H.T.; R.W. TAYLOR; M.W.J. CROSLAND; H.R. \& H.R. CROZIER. 1988. Modes of spontaneous chromosomal mutation and karyotype evolution in ants with reference to the minimum interaction hypothesis. Jpn. Jour. Genet. 63: 159-185.

LEVAN, A.; K. FredGA \& A.A. SANDBERG. 1964. Nomenclature for centromeric position on chromosomes. Hereditas 52: 201-220.

MANI, M.S. 1964. Ecology of Plant Galls. The Hague, W. Junk, V+640p.

MAVRAGANI-TSIPIDOU, P.; G. KaRAMANLIDOU; A. ZaChaROPOULOU; S. Koliais \& C. KASTRITSIS. 1992. Mitotic and polytene chromosome analysis in Dacus oleae (Diptera: Tephritidae). Genome 35: 373-378.

Silva, I.M.; G.I. Andrade; G.W. Fernandes \& J.P.L. Filho. 1996. Parasitic relationships between a gall-forming insect Tomoplagia rudolphi (Diptera: Tephritidae) and its host plant (Vernonia polyanthes, Asteraceae). Ann. Bot. 78: 45-48.

Solferini, V.N. \& J.S. MoRGante. 1987. Karyotype study of eight species of Anastrepha (Diptera: Tephritidae). Caryologia 40: 229-241.

ZACHAROPOUlOU, A. 1987. Cytogenetic analysis of mitotic and salivary gland chromossomes in the Medfly Ceratitis capitata. Genome 29: 67-71.

Zambetaki, A.; K. Kleanthous \& P. Mavragani-Tsipidou. 1995. Cytogenetic analysis of malpighian tubule and salivary gland polytene chromosomes of Bactrocera oleae (Dacus oleae) (Diptera: Tephritidae). Genome 38: 1070-1081.

Recebido em 06.VIII.1998; aceito em 26.XI.1999. 